\title{
A study on the behavior of beam-column connections in precast concrete structures: experimental analysis
}

\section{Estudo do comportamento de ligações viga-pilar em estruturas pré-moldadas de concreto: análise experimental}
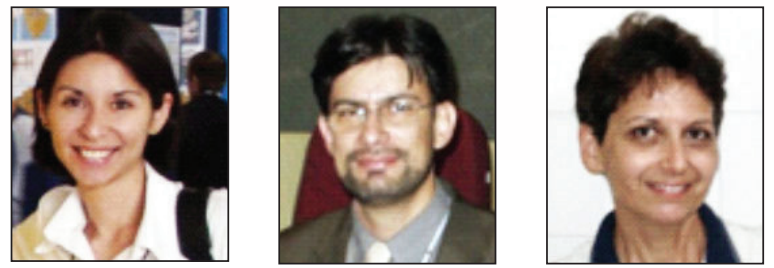

M. N. KATAOKA kataoka@sc.usp.br

M. A. FERREIRA marcelo@ufscar.br

A. L. H. C. EL DEBS c analucia@sc.usp.br

\section{Abstract}

Due to the large increase in the use of precast concrete structures in multistory buildings, this work covers a study on the behavior of beam-column connection with emphasis on the continuity provided by the slab reinforcement. Two prototypes were tested, each one with a different detail of the continuity reinforcement distribution. In both connections, the steel area used on the concrete cover of the hollow core slab was the same, varying the amount of bars that passed through the column and the ones that were placed adjacent to the column. The experimental results showed that the connection with bars adjacent to the column presented stiffness increase and a better cracking control. According to the classification the two tested connections can be considered semi-rigid.

Keywords: precast concrete, semi-rigid connection, beam-column connection.

\section{Resumo}

Em decorrência do grande aumento na utilização de estruturas pré-moldadas de concreto na construção de edifícios de múltiplos pavimentos, abordou-se neste trabalho o estudo do comportamento de ligações viga-pilar com ênfase na continuidade proporcionada pela armadura da laje. Dois protótipos foram ensaiados, cada um deles com um detalhamento diferente de distribuição da armadura de continuidade. Em ambas as ligações, a área de aço utilizada na capa da laje foi a mesma, variando a quantidade de barras que passavam através do pilar por meio de aberturas e as que se localizavam em suas laterais. Os resultados experimentais mostraram que a ligação com barras laterais ao pilar apresentaram aumento da rigidez e maior controle da fissuração. De acordo com a classificação realizada, as duas ligações ensaiadas podem ser consideradas semi-rígidas.

Palavras-chave: concreto pré-moldado, ligação semi-rígida, ligação viga-pilar.

\footnotetext{
a Department of Structural Engineering, School of Engineering of São Carlos, University São Paulo, kataoka@sc.usp.br, Trabalhador Saocarlense Avenue, $n^{\circ}$ 400, CEP: 13566-580, São Carlos, SP, Brazil.

b Department of Civil Engineering, Federal University of São Carlos, marcelo@ufscar.br, Via Washington Luís, km 235, CEP: 13565-905, São Carlos, Brasil. - Department of Structural Engineering, School of Engineering of São Carlos, University São Paulo, analucia@sc.usp.br, Trabalhador Saocarlense Avenue, $n^{\circ}$ 400, CEP: 13566-580, São Carlos, SP, Brazil.
} 


\section{Introduction}

The researches about the behavior of precast concrete structures are very important for the modernization of the Civil Construction Industry, mainly to improve the quality, productivity and to promote the rationalization on sites.

After the Second World War, the precast concrete structures were so much used to reconstruct the Europe. In this period, new methods and constructions techniques that emphasize the rationalization and the productivity became necessary to boost the prefabrication. The large-scale and the few available workers were the main reasons for the development of the precast concrete structures.

The use of precast concrete structures is increasing in Brazil. The reason for this growth is the efficiency of this type of structure to meet the market requirements that are the compliance with deadlines and technical quality. These requirements are important for buildings mainly which have large spans, for example, industrial buildings.

The main difference between precast concrete structures and the traditional reinforced concrete structures is the presence of connections. Therefore, the study of the connections behavior stands out in the field of precast concrete structures. The connections behavior has an important role because it is responsible for transmission and redistribution of the stress. The ABNT NBR 9062 [1] is the Brazilian Code that governs the design and construction of precast concrete structures. This code has received many contributions from several studies involving the behavior of connections with the intention of spreading the technical knowledge obtained and usual the use of this type of structure.

The connections are regions that have a complex behavior. In these regions occur stress concentrations and for this reason the connections deserve a special attention of the researchers and the designers. In general, the connections between precast elements do not behave exactly as they are considered in the structural analysis. The designers consider that the connections allow or prevent entirely the relative displacements between the connected elements, which do not happen. What happens is that the connections have an intermediate behavior and must be called as semi-rigid. However, the development of this type of connection is extremely important to enable the use of precast concrete system in multistory buildings.

\section{Analysis of semi-rigid connections}

The connections have been defined as "semi-rigid" in the study of precast concrete structures since the 1980s. This term has been used since 1930 to designate connections in steel structures and now it is becoming common among researchers in the field of prefabricated structures.

Several types of studies on precast concrete connections have been done in research centers around the world. In general, studies include the development of connections which provide high rigidity and easiness of implementation. In the research of Shariatmadar and Beydokhti [2] was tested a connection between precast beam and column preformed without the use of corbel. The region which joins the elements was cast in situ. The improvement of the bending moment transfer to the column by the use of prestressed reinforcement was another way found by the researchers to improve the connections behavior. Hawileh et al. [3] performed a numerical and experimental study of connections involving prestressed reinforcement. The authors compared both results and they concluded that computer simulation is an economical option to analyze the behavior of connections. Following this line of study, Kaya and Arslan [4] also analyzed beam-column connections with prestressed reinforcement. They noted that for different levels of prestressing applied, the connections presented satisfactory behavior. In the literature review was found that the use of prestressed reinforcement in precast concrete connections has been studied for a long time. The search of Saqan [5] is one of these stud-

\section{Figure 1 - Indication the local of load application and the node of a porch structure analyzed}

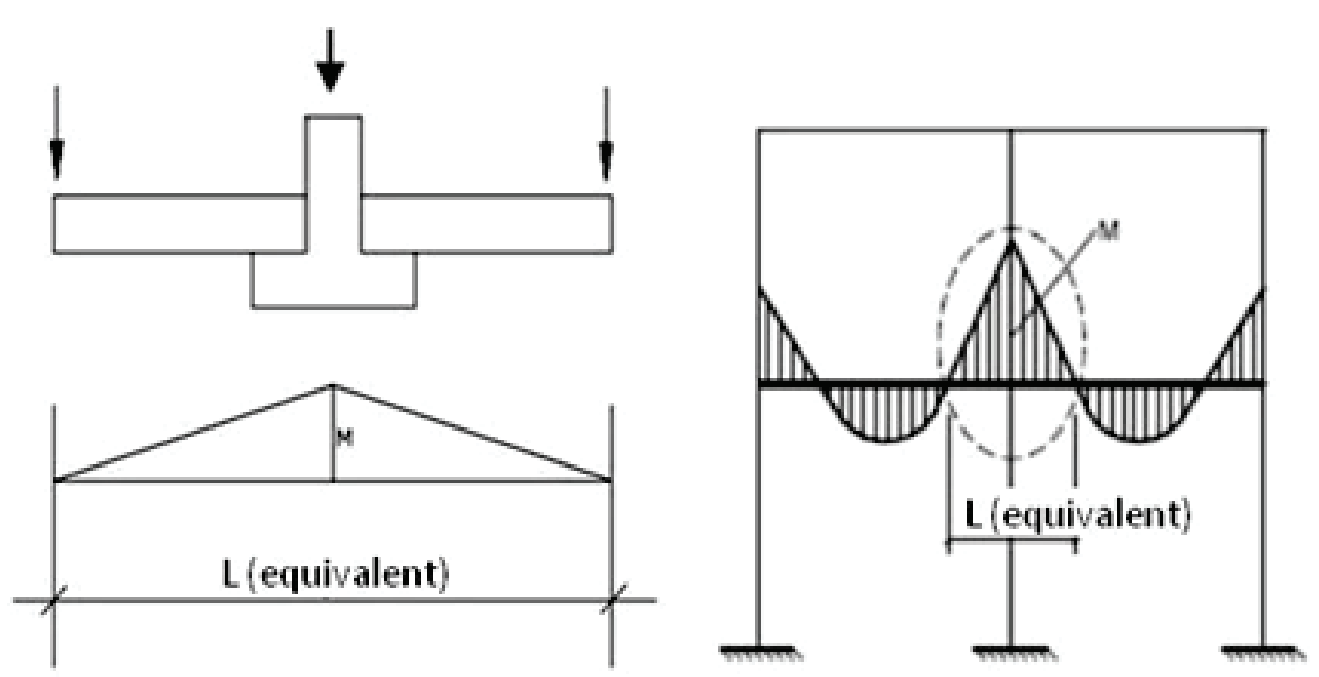


Figure 2 - Details of beams reinforcement

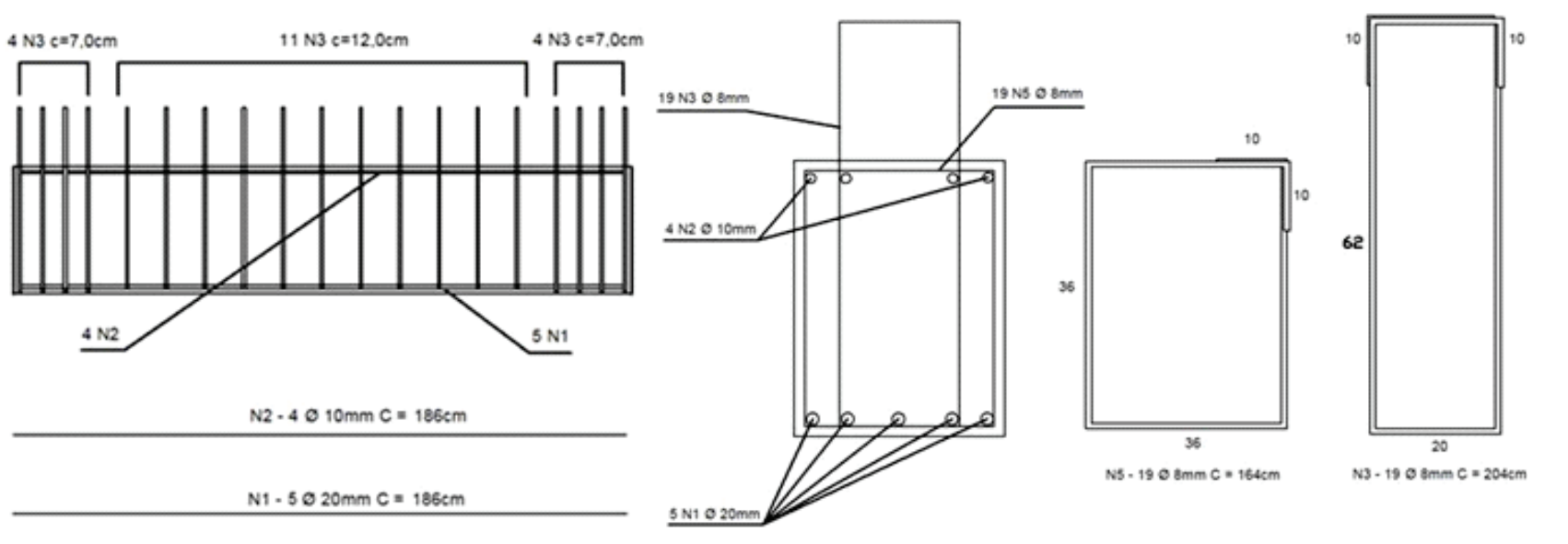

ies. Saqan [5], a researcher of the University of Texas, tested various configurations of connections that would provide to the structure a rigidity behavior when subjected to earthquakes. The connections developed did not have concrete cast on site and should be economical and ductile. This research had an objective to increase the knowledge about the behavior of this type of connection in order to increase the utilization of precast concrete structures in the United States.

Many researches about precast concrete connections were also performed in Brazil. A current search that can be mention is Oliveira Junior [6] which studied the behavior of a type of beam-column connection for use in hydroelectric power plants. This connection was made with cast on site concrete, using concrete fiber and steel threaded sleeves to provide continuity to the reinforcement and consequently high rigidity.

Baldissera [7] studied a type of connection with inclined dowels. To analyze the behavior of this connection, the results of the test of this connection with inclined dowels were compared to the behavior of the conventional connections with straight dowels. The conclusion of the comparison was the rigidity increase with the innovated detail. In this context, this paper aims to analyze the behavior of the beam-column connections in precast concrete structures with the focus on the details of the slab reinforcement. The influence of the distribution of the bars in the slab in order to improve the transfer of stress was analyzed, even as the distribution of cracking in this region.

\section{Experimental program}

The experimental program of this paper was performed in Kataoka [8] and it aimed to analyze the interaction of the beam end with the column. Two prototypes with cruciform arrangement were constructed to be tested. They were constituted by a central continuous column with two cantilever beams. The vertical action was applied at the end of the beams, as illustrated in Figure 1. This arrangement enabled the simulation of a region near a central node of a porch structure.

\subsection{Design of the connection}

The two prototypes were dimensioned to resist the application of $150 \mathrm{kN}$ on each beam and the design was done according to the requirements of [1], [9] and [10]. The column had cross section area of $500 \mathrm{~mm} \times 400 \mathrm{~mm}$ and $1400 \mathrm{~mm}$ of height, concrete corbel with $400 \mathrm{~mm} \times 250 \mathrm{~mm}$ and dowels with $20 \mathrm{~mm}$ in diameter. The beams had cross section area of $400 \mathrm{~mm} \times 400 \mathrm{~mm}$ in their precast part and after the assembly, $200 \mathrm{~mm}$ of cast on site concrete were added. This concrete cover filled the beams and the slab at the same time and it promoted the integration with the negative reinforcement. The reinforcement details of these elements are shown in Figures 2 and 3.

The negative reinforcement was located on the side of the column and passing through the column by holes. In prototype called Model 1, the reinforcement just passed through the column and in the prototype called Model 2, the bars were distributed in the side of the column and crossing it, both on the precast slab. The slab used on Model 2 was the hollow core slab with $200 \mathrm{~mm}$ in height and cast on site concrete cover with $70 \mathrm{~mm}$ of thickness. The cantilever slab had $400 \mathrm{~mm}$ of length which was measured from the face of the beam. The bars on side of the column were distributed on a range of $250 \mathrm{~mm}$, which also was measured from the face of the column. Figure 4 shows the dimensions of the pieces of hollow core slabs used on Model 2.

The longitudinal continuity reinforcement was integrated to the structure with $270 \mathrm{~mm}$ of height of concrete casting on site on the precast beams in order to improve the flexural strength of the connection. This height was constituted by two layers: $200 \mathrm{~mm}$ of the beams and $70 \mathrm{~mm}$ of concrete cover on the hollow core slab.

The steel area (As) used in the models was $804 \mathrm{~mm}^{2}$. In the situation that $100 \%$ of the reinforcement passed inside the column (Model 1), this reinforcement consisted of 4 bars of $16 \mathrm{~mm}$ of diameter. It is important to say that Model 1 had no slab. In Model 2, which had $50 \%$ the reinforcement passing inside the column and $50 \%$ outside, two bars of $16 \mathrm{~mm}$ of diameter passing inside the column and 4 bars of $8 \mathrm{~mm}$ of diameter on each side were used. 
As already mentioned these bars were distributed over a range of $250 \mathrm{~mm}$ (Table 1).

In addition to the continuity reinforcement of the connection, the concrete cover of the slab also had a steel mesh that overlapped the negative reinforcement. This steel mesh had $100 \mathrm{~mm}$ spacing between the wires. The wires had $4.5 \mathrm{~mm}$ of diameter and steel area of $1.59 \mathrm{~cm}^{2} / \mathrm{m}$ in two directions. Model 2 also had transverse reinforcement which was located on both sides of the column, comprising a total of 6 bars of $8 \mathrm{~mm}$ of diameter. These bars were positioned $150 \mathrm{~mm}$ from the center of gravity of the reinforcement.

\section{Figure 3 - Details of corbels reinforcement}

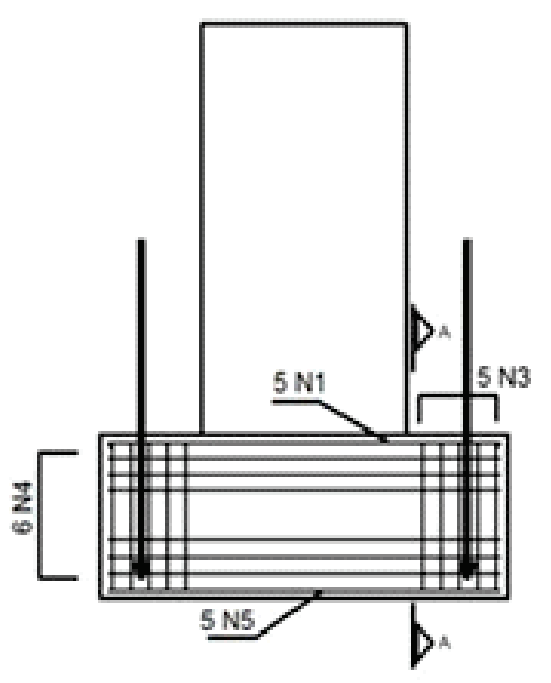

96

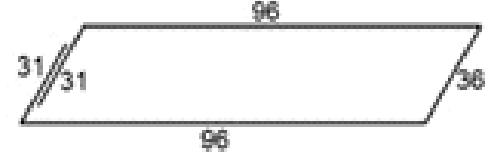

$\mathrm{N} 4.6 .08 \mathrm{~mm} \mathrm{C}=290 \mathrm{~cm}+5.0 \mathrm{~cm}$

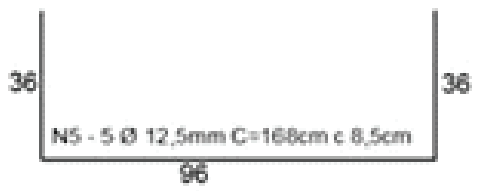

N1 - 5 O $12.5 \mathrm{~mm} \mathrm{C}=96 \mathrm{~cm}$

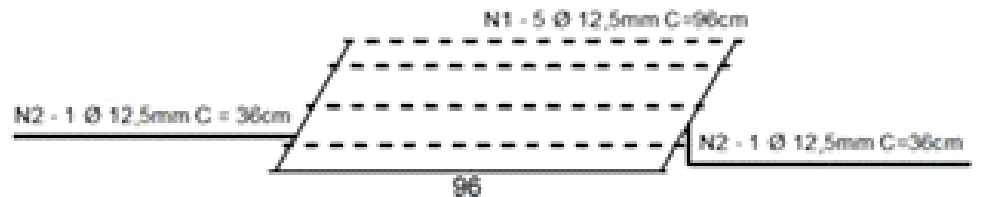

SECTION A - A

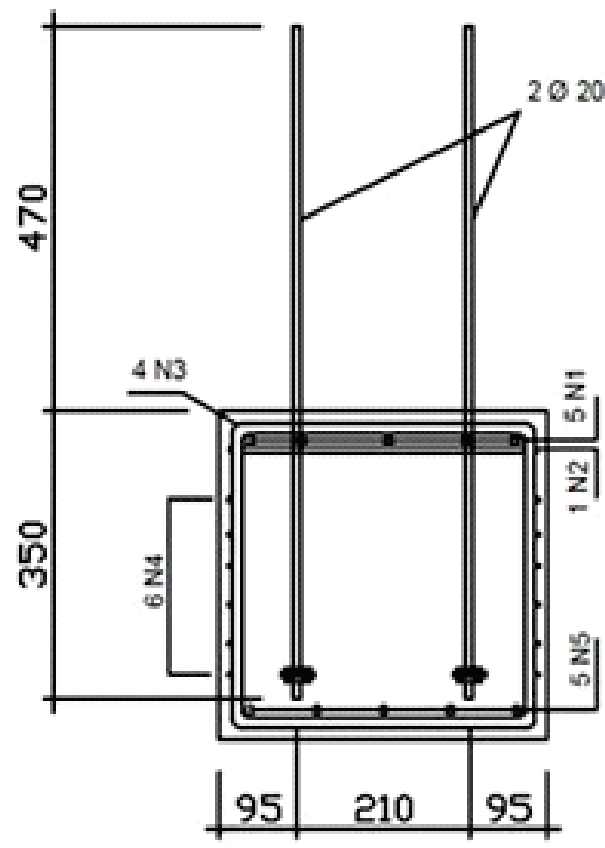

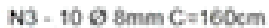

10

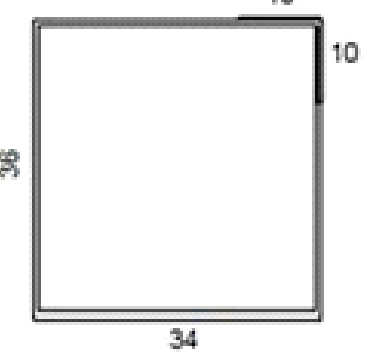

N1 - $5012 \operatorname{senm} \mathrm{C}=9 \mathrm{gecm}$

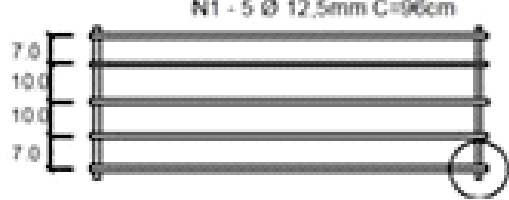


Figure 4 - Dimensions of the pieces of hollow core slabs
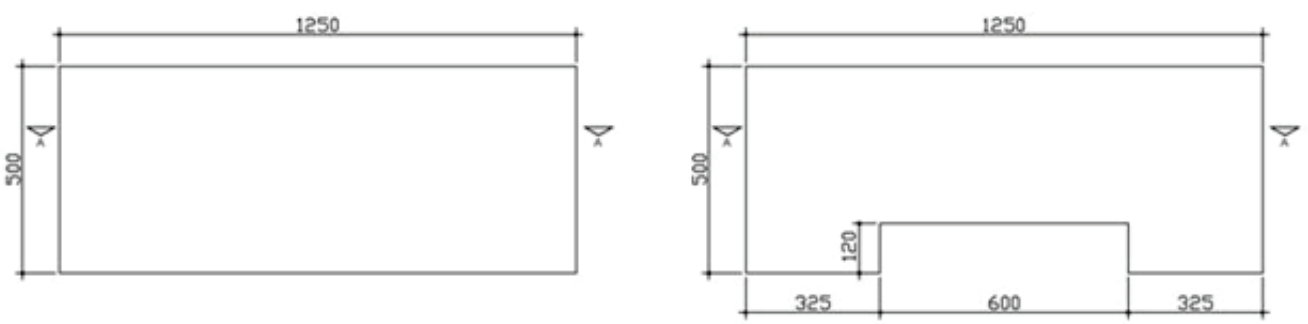

SECTION A - A

SECTION A - A
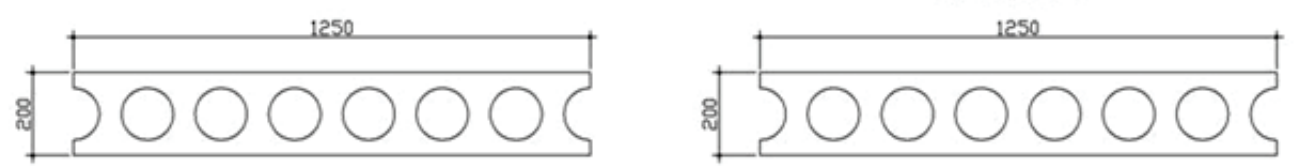

Table 1 - Summary of continuity reinforcement used in the models

$\begin{array}{cccc}\text { Model } & \text { Reinforcement } & \text { Quantity } & \mathbf{A}_{\mathrm{s}}\left(\mathrm{mm}^{2}\right) \\ \text { Model 1 } & \text { Internal -inside the column } & 4 \phi \text { de } 16 \mathrm{~mm} & 804 \\ \text { Model 2 } & \text { External - in the lateral of the column } & - & 2 \phi \text { de } 16 \mathrm{~mm} \\ & \text { Interna - inside the column } & 8 \phi \text { de } 8 \mathrm{~mm} & 804\end{array}$

\section{Figure 5 - Dimensions of Model 1}
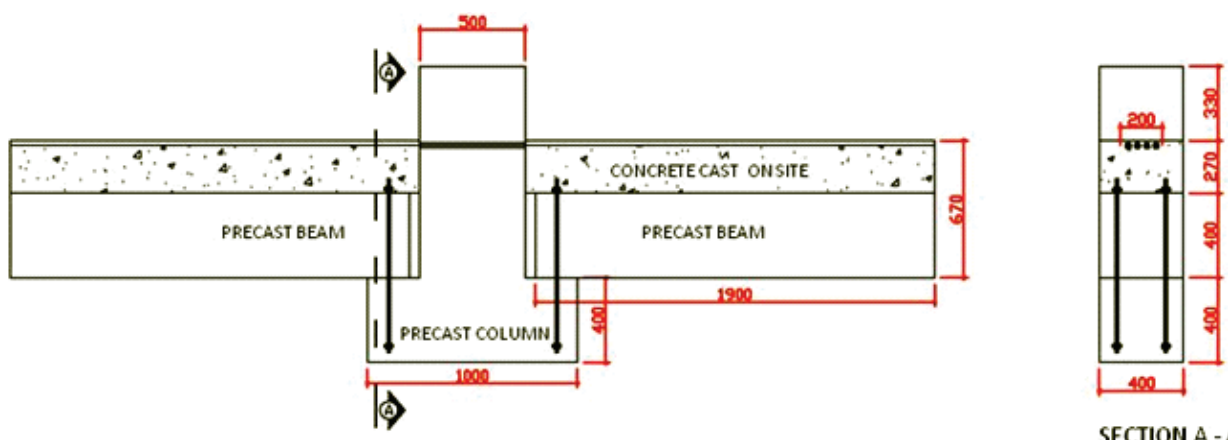

SECTION A - A

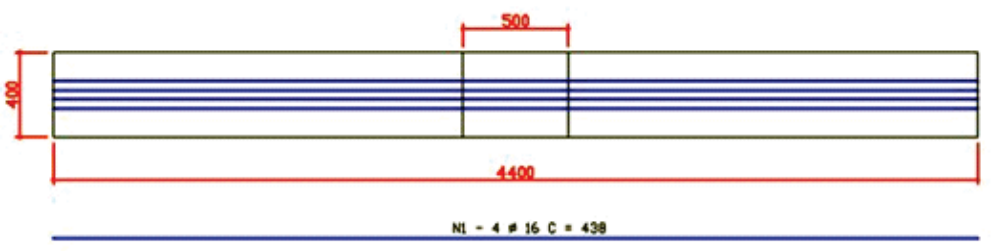


Figure 6 - Dimensions of Model 2
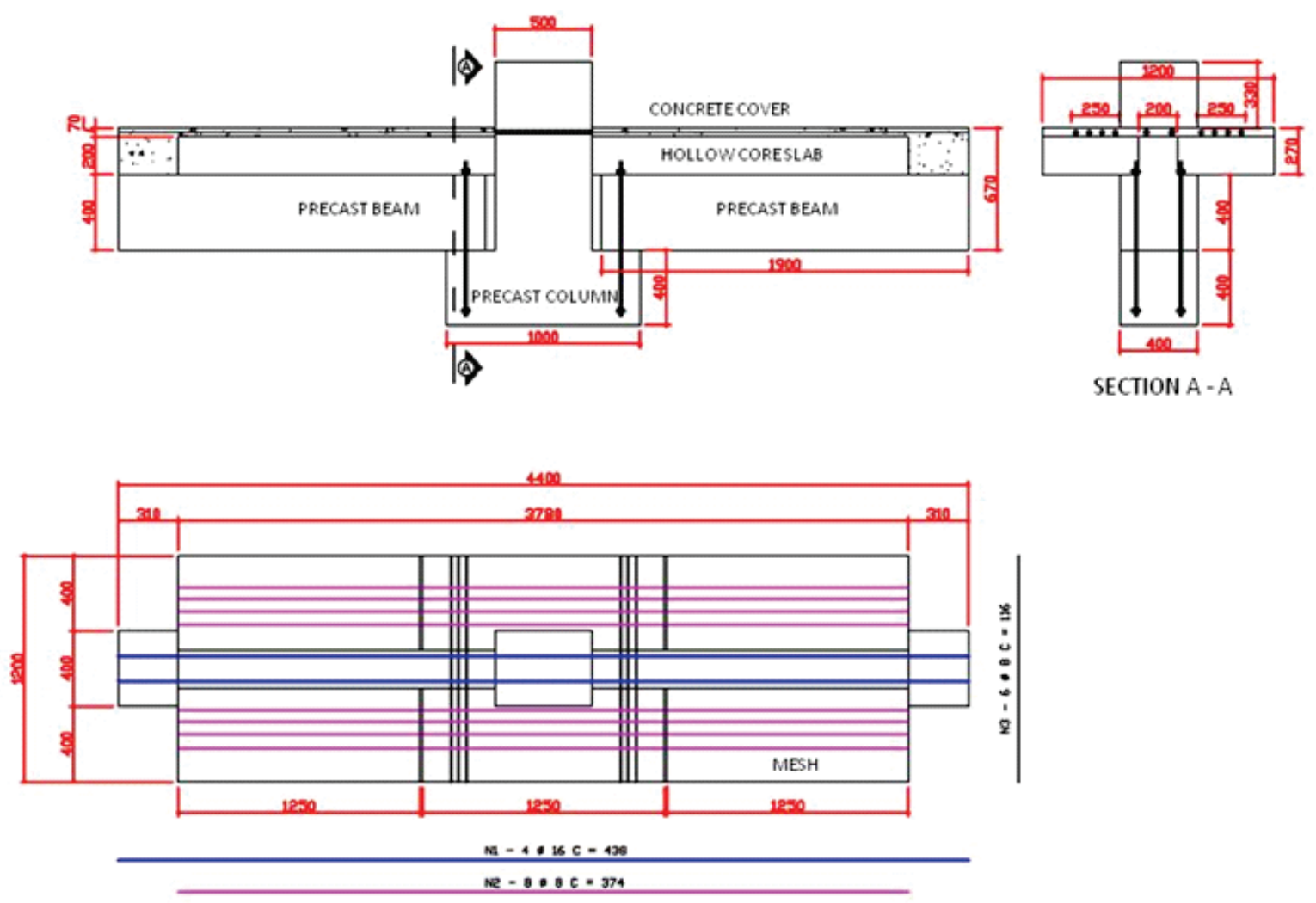

Figure 7 - The assembly sequence of Model 1
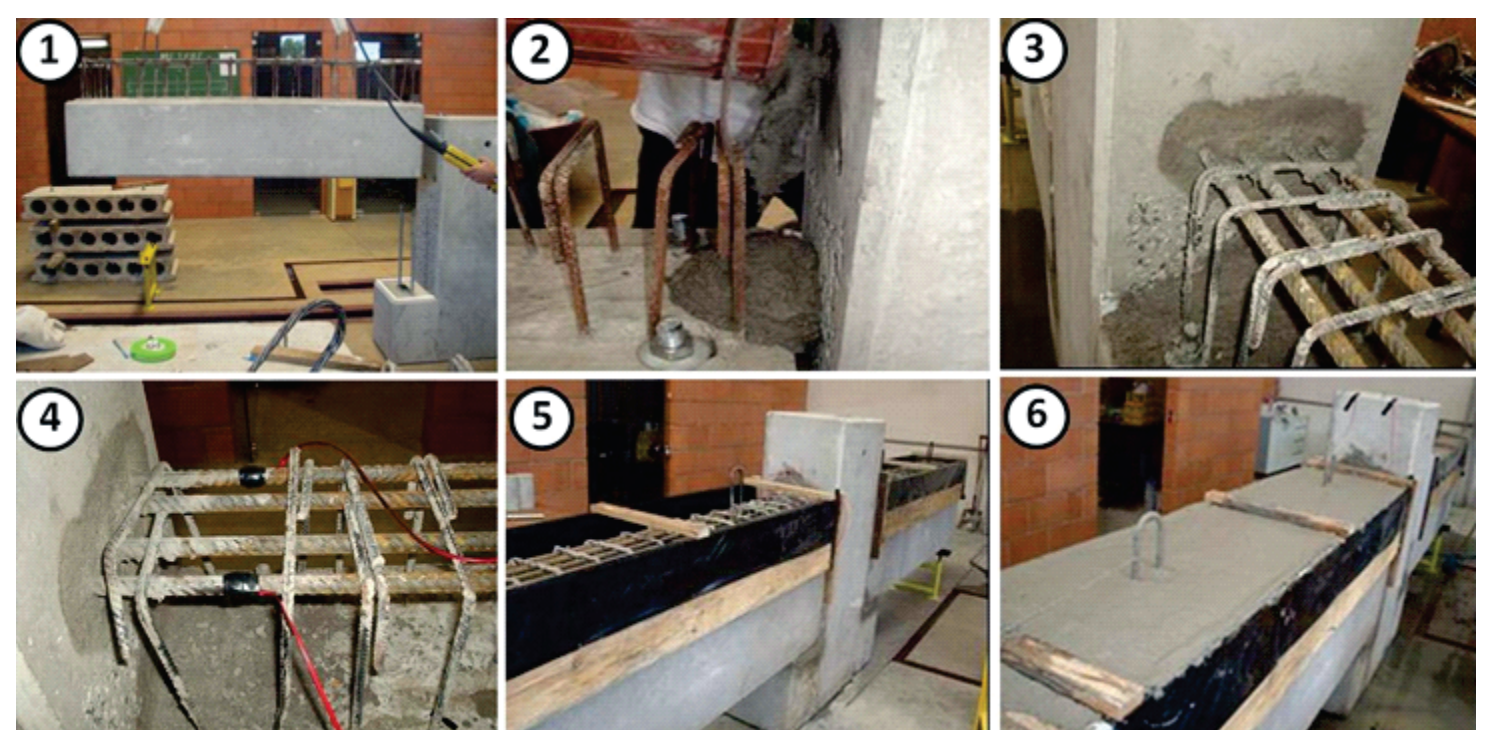

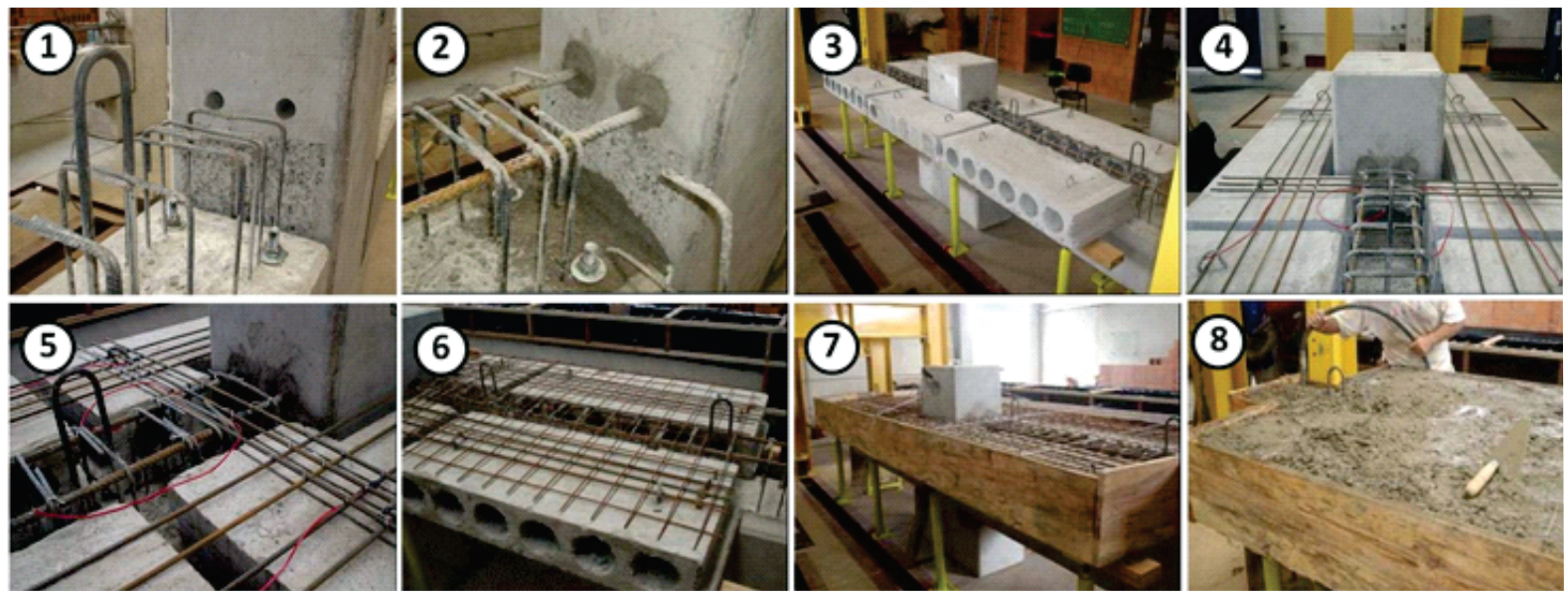

\subsection{Construction of models}
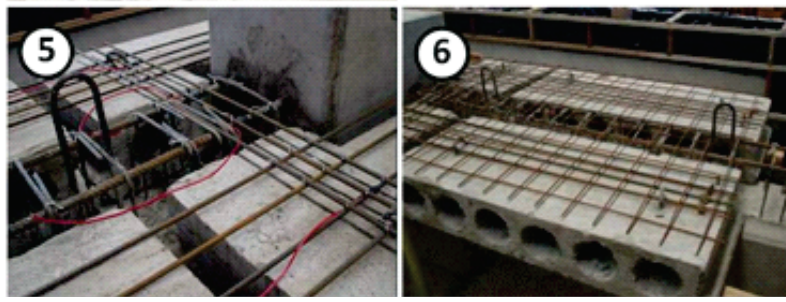

The assembly sequence of Model 1 was as follows (Figure 7):

1. Attaching the beams in the dowels, which were located in the corbels;

2. Filling the beam-column interface and the hole of the dowels with grout;

3. Placement of continuity reinforcement and filling the column hole with grout;

4. Bonding of strain gages;

5. Assembly of timber shapes;

6. Concrete casting.

The assembly of Model 2 was more complex due to the presence of the slab requires that more time for its construction. Apart from the construction of the slab, the correct positioning of the negative reinforcement also needed to be done with care and precision. The

assembly sequence followed the steps listed below (Figure 8):

1. Placement of the beams;

2. Placement of the continuity reinforcement and the filling of the holes of the column, the holes of the dowels and the beamcolumn interface with grout;

3. Assembly of the hollow core slab;

4. Assembly of the reinforcement in the lateral of the column and the transverse bars;

5. Instrumentation of the continuity reinforcement;

6. Placement of the steel mesh;

7. Assembly of timber shapes;

8. Concrete casting.

\subsection{Instrumentation}

In the tests, various measurement instruments were used, each

Figure 9 - Rotation measuring instruments (clinometers and transducers)
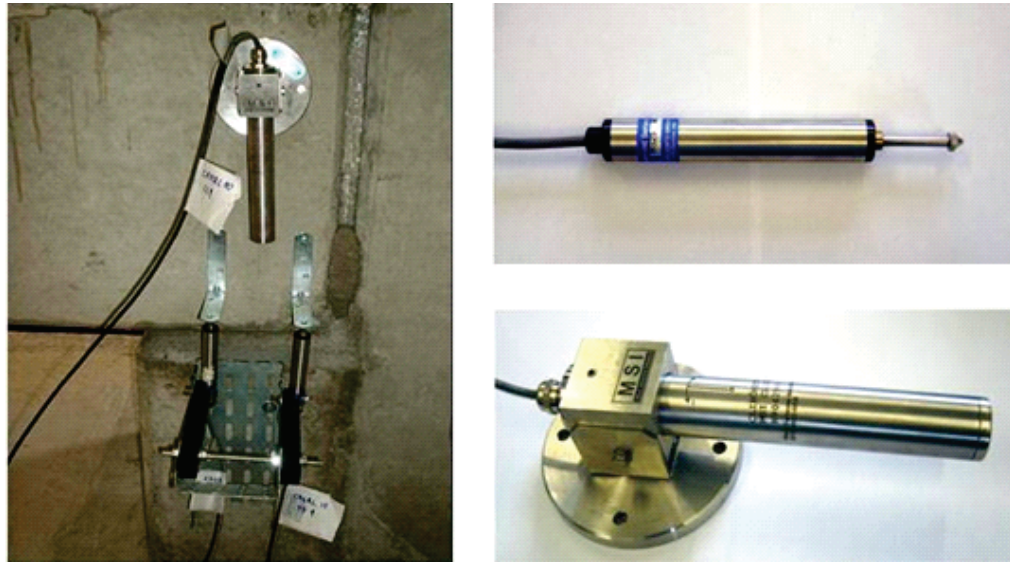
one with a specific function:

- Hydraulic cylinder: load application;

- Strain Gages: measuring the strain in the negative reinforcement;

- Clinometers: measurement of rotations;

- Extensometers with removable base: measurement of displacements;

- Transducers: displacement measuring.

In order to determine the beam-column relative rotations transducers positioned on the corbel were used, following the same scheme adopted by [12]. Clinometers were used to measure the global rotation of the connection and transducers with removable base were also used to the same intention, as indicated in Figure 9. The use of clinometers is innovative for this purpose, so another method to measure the rotation already tested was used, as mentioned about the transducers. Figure 10 illustrates the layout of the prototypes instrumentation.

\subsection{Test set up}

In the test set up were used three reaction frames each one with a hydraulic jack. Two of them were placed at the end of the beams for monotonic load application. The third one was placed on the top of the column to the hydraulic jack apply a constant load. Figure 11 shows the final configuration of the test set up.

The hydraulic jack located at the top of the column applied a constant force of $170 \mathrm{kN}$ during all the test with the intention to simulate the loading come from up floors and also to stabilize the model. The clearances in the structure were eliminated by applying a force of $30 \mathrm{kN}$ and after this procedure the test began with the application of the incremental monotonic load.

In the tests, a vertical load was applied in the end of the beams generating negative bending moment on both sides of the column. The distance from the point of load application to the center of connection rotation was $1.70 \mathrm{~m}$. Under this point it was measured the vertical displacement, which configures an important parameter for analyzing the behavior of the connection as well as the rotation generated.

Figure $10-$ Instrumentation of Models 1 and 2
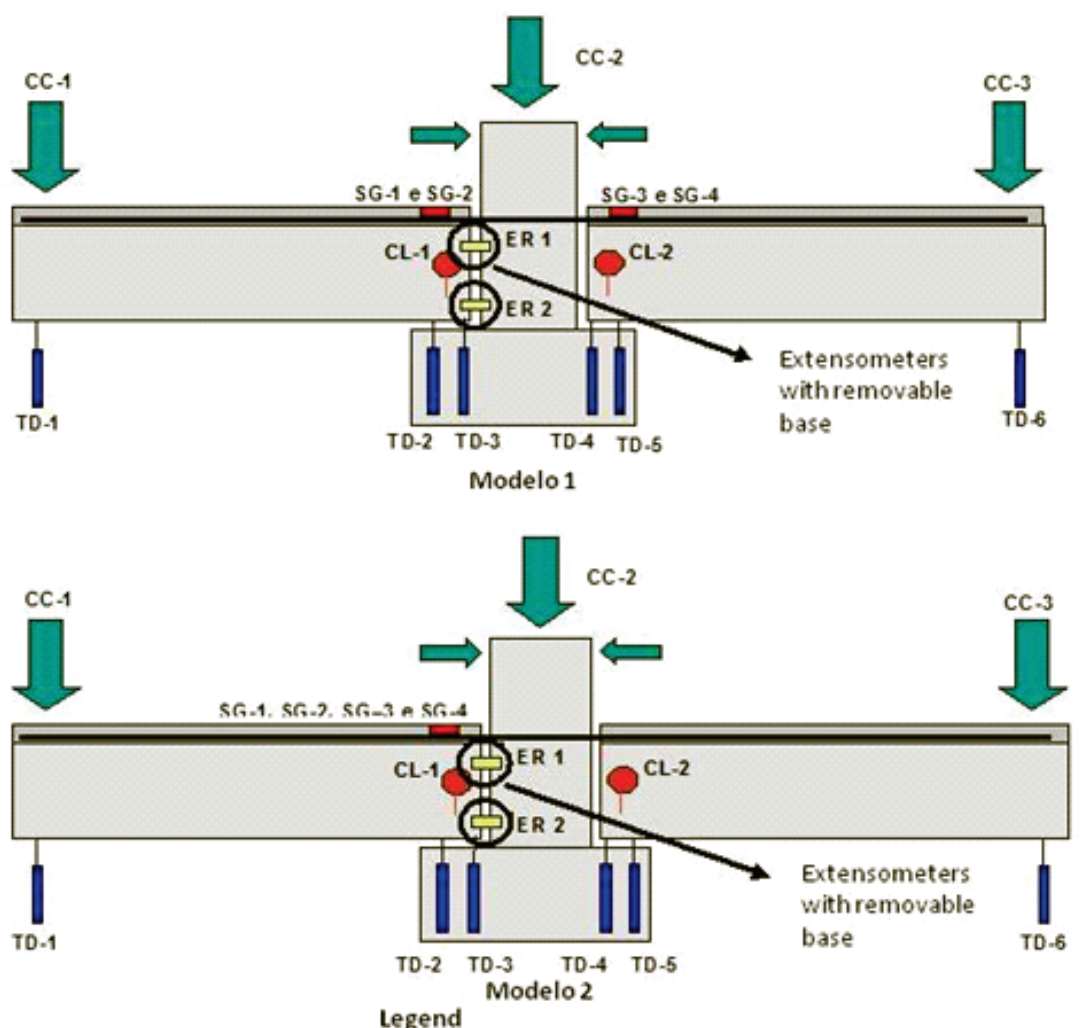

Legend

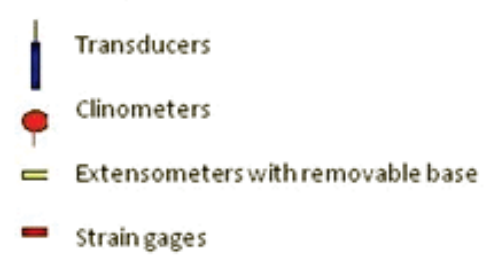




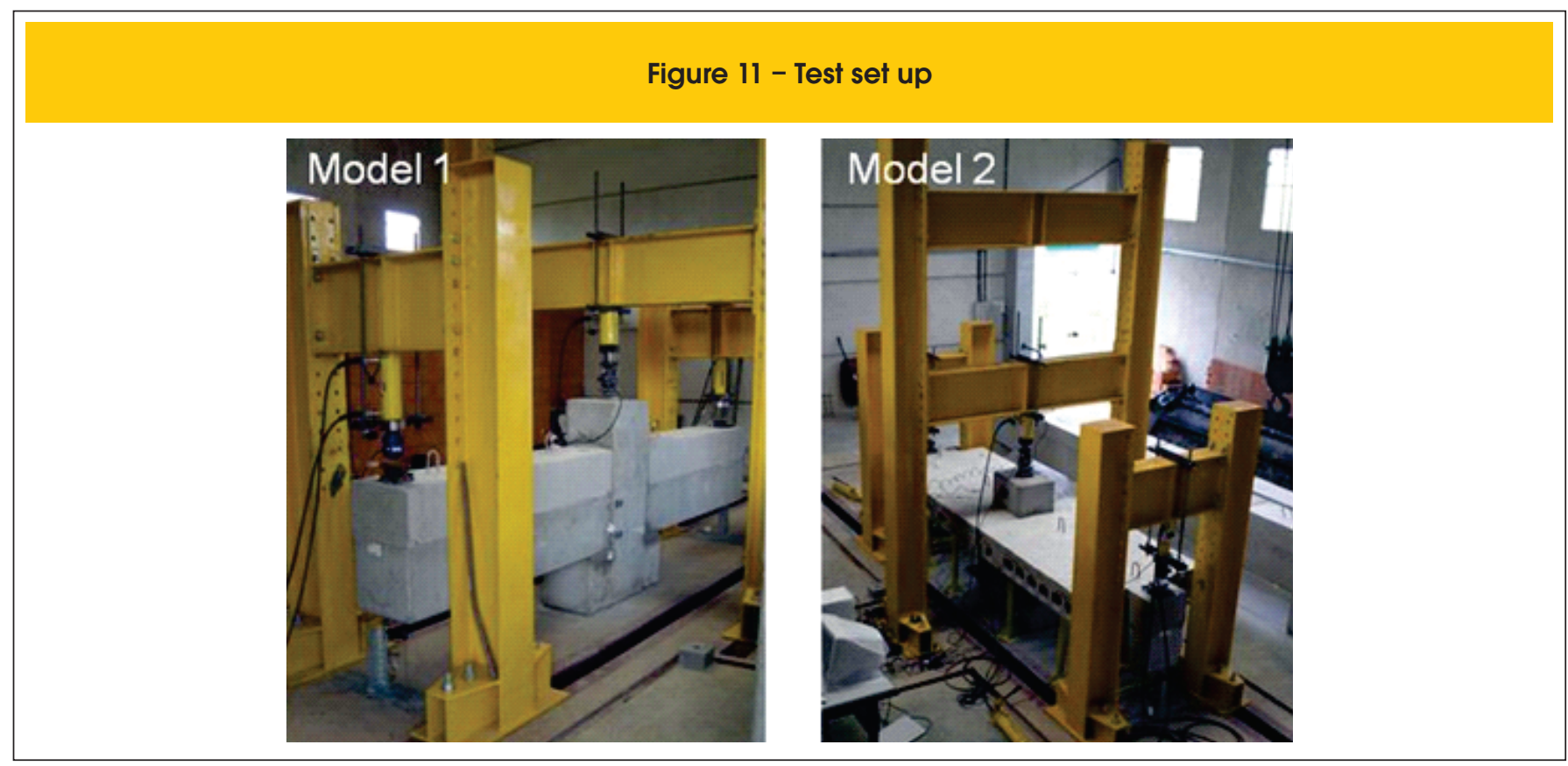

\subsection{Mechanical properties of materials}

\subsubsection{Concrete}

The compressive strength of cast on site concrete was obtained by testing three cylindrical specimens with dimensions of 200 $\mathrm{mm} \times 100 \mathrm{~mm}$. The characterizations tests were conducted one day after the test of the connections, when the specimens were eight days old. The average of the compressive strength was 25, $7 \mathrm{MPa}$.

The values of the compressive strength of the precast concrete elements were reported by manufacturer. The compressive strength was about $40 \mathrm{MPa}$ and the elastic modulus was $30270 \mathrm{MPa}$.

Figure 12 - Bending moment versus rotation curves with the indication of secant stiffnesses (red lines)

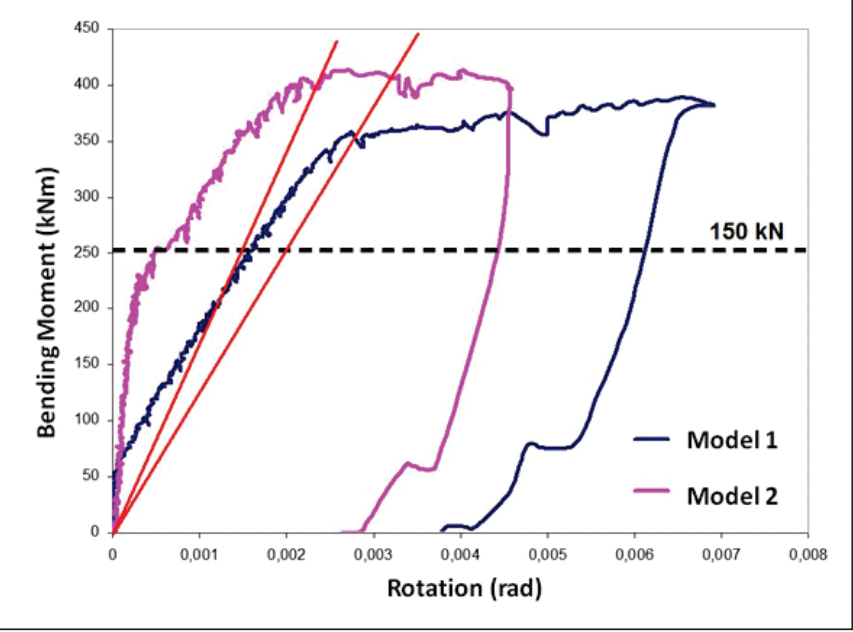

\subsubsection{Grout}

The grout was used to fill the interface between the beam and the column, the hole of the dowels and hole in the column where the continuity reinforcement was located. The type of grout used in the prototypes was a mixture based on cement Portland, natural aggregates and additives which allow the utilization in operations of anchorage.

This product develops high mechanical strength without shrinkage and it is indicated to grout services or to be used as mortar repairs. This grout was chosen due to its fluidity maintained for a long time, which allows working in hard to reach areas like the case of the fulfillment of the holes and the interfaces. According to manufacturer's data, this grout can achieve a compressive strength of $20 \mathrm{MPa}$ in twenty-four hours and $52 \mathrm{MPa}$ at twenty-eight days.

The characterizations tests of the cylindrical specimens of grout were performed with 26 days and the results confirmed the data provided by the manufacturer. Thus, it can be considered that in the date of the connections test, when the grout was 15 days old, it had reached $40 \mathrm{MPa}$ of compressive strength.

\section{Experimental results}

The tests of the connections models tested presented satisfactory behavior because they reached a load which exceed the

Table 2 - Stiffnesses of Model 1 and 2

\begin{tabular}{|ccc|} 
Model & $\begin{array}{c}\text { Secont stifiness } \\
\mathrm{kNm} / \mathrm{rad}\end{array}$ & $\begin{array}{c}\text { Project stifiness } \\
\mathrm{kNm} / \mathrm{rad}\end{array}$ \\
\hline 1 & 120689 & 155772 \\
2 & 181818 & 511993 \\
\hline
\end{tabular}




\section{Figure 13 - Load versus rotation curves for the three methods of rotation measurement}

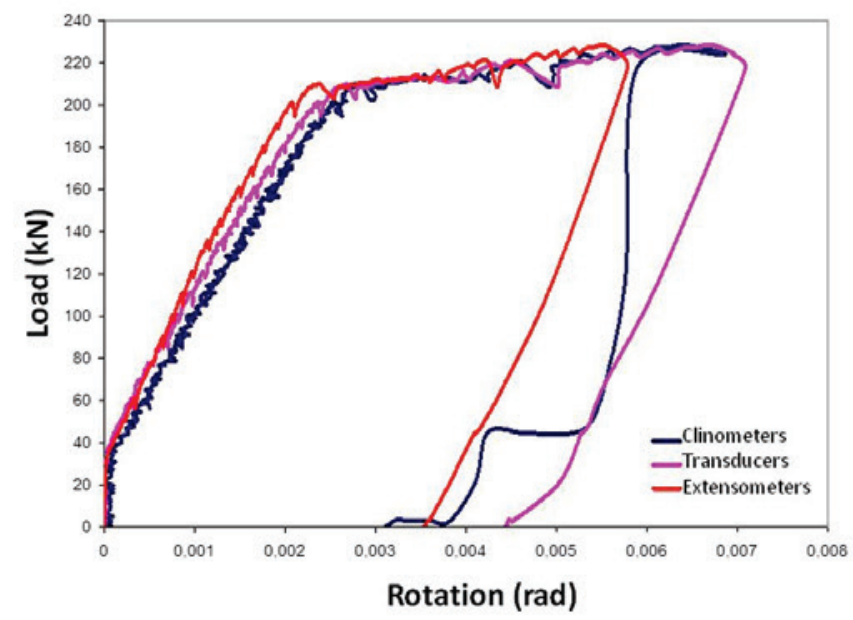

Model 1

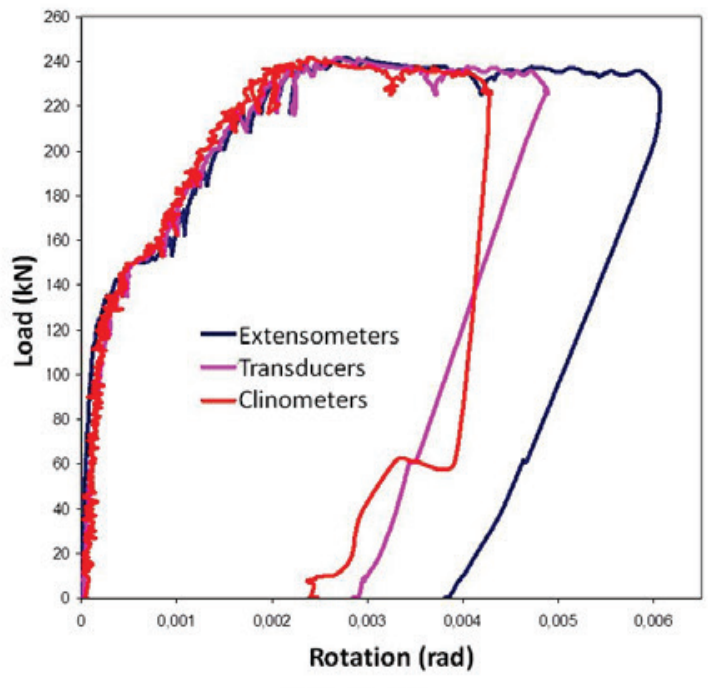

Model 2 maximum load determine in their project, which was $150 \mathrm{kN}$. This performance can be attributed to the design details and to the care taken during the construction of the models. In order to improve the connection behavior, a greater number of stirrups at the ends of the beams were concentrate, minimizing the cracking and avoiding the slippage between the precast concrete and the cast on site concrete.

The stirrups height was higher than it is usually determined in a project which is the same height of the beam. In the models the stirrups reached the concrete cover of the slab, where the continuity reinforcement was located at the same level. This detail was used to distribute the stress between all bars. The transverse reinforcement was used to reduce the stress in the connection and to distribute the cracks. In Model 2, the cracking began on the beams and not in the connection as usual.

In the construction of the bending moment versus rotation curve was used the average of the rotations and the bending moments of the right and left sides. Comparing the curves of the two models, Model 2 presented experimental stiffness higher than Model 1 , the difference reached $65 \%$. Comparing the secant stiffness, this difference between the models was lesser, about $22 \%$. Figure 12 shows the bending moment versus rotation curves for comparison between the behavior of Model 1 and 2. Table 2 contains the values of secant stiffness and project stiffness for Models 1 and 2 .

Three types of rotation measurement were performed during the tests in order to examine the most appropriate. All methods used (transducers, clinometers and extensometers with removable base) provided similar values, and the data obtained by clinometers was used in the construction of the bending moment versus rotation curves. Figure 13 presents the load versus rotation curves for each measurement method to compare the results.

For each model, the force versus strain curves of the continuity reinforcement were drawn based on the average values of steel bars strain. It was possible because there were no differences between the behaviors of the bars. Comparing the curves in Figure 14, the difference between the connections behavior can be note because for the same reinforcement ratio and the same load, in some situations Model 1 showed high strain, up to $100 \%$. This fact may have occurred because Model 2 had slab and the stresses were distributed in a larger number of bars, despite having the same steel area of Model 1.

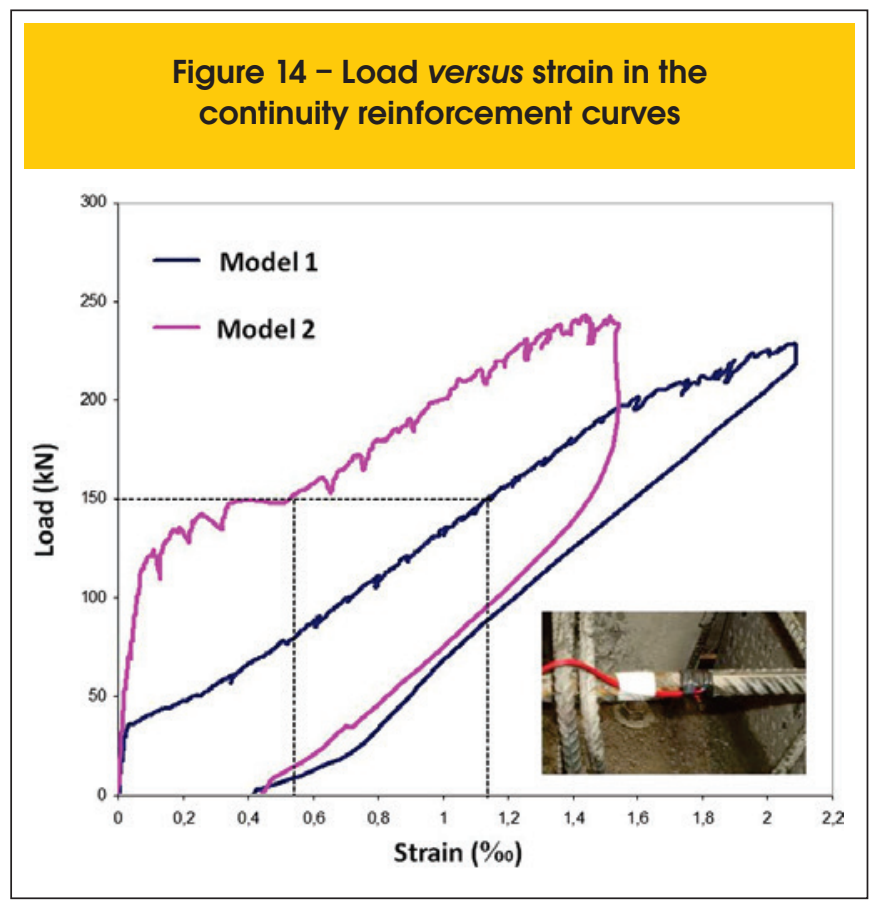


Figure 15 - Classification system of connections proposed by Ferreira et al. (2002) (13)

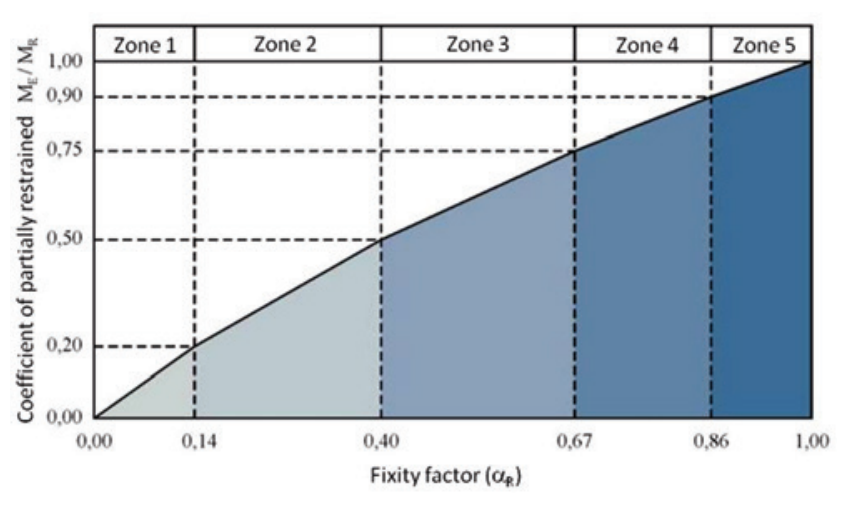

\section{Classification of connections}

In Ferreira et al. [13] is presented a connection classification system that subdivided the connections into five distinct zones, as shown in Figure 15. This classification system is based on fixity factor $\left(a_{R}\right)$ (equation 1 ) and on the coefficient of partially restrained $\left(M_{E} / M_{R}\right)$. The fixity factor $\left(a_{R}\right)$ is a non-dimensional parameter that associates the rotational stiffness of the connection with the stiffness of the precast beam, varying from 0 (pinned) to 1 (rigid). The coefficient of partially restrained represents the ratio between the partially restrained end moment $\left(M_{E}\right)$ and the fully restrained moment $\left(M_{R}\right)$.

According to this classification, zone 1 corresponds to the pinned connections, zones 2 to 4 correspond to semi-rigid connections of low, medium and high strength, respectively, and zone 5 corresponds to rigid connections.

$$
\alpha_{R}=\frac{1}{1+\frac{3(E I)_{\mathrm{sec}}}{R_{\mathrm{sec}} \cdot L_{e f}}}=\frac{\theta_{1}}{\theta_{2}}
$$

$(E I)_{\text {sec }}$ - Secant stiffness of the beam according to [9]

$L_{\text {ef }}$ - Span between supports, distance between rotation centers of the supports

$R_{\text {sec }} \quad$ - Secant stiffness of the beam-column connection

$\theta_{1}-$ Rotation at the beam end

$\theta_{2}-$ Combined rotation of the beam end and the connection

To analyze the connections behavior was used the Beam-Line Method. To construct this line it was necessary to determine the maximum rotation for a pinned connection as indicated in Figure 17. The analysis was performed considering a beam with $5.8 \mathrm{~m}$ of length with two concentrated loads of $180 \mathrm{kN}$. This structure was considered because in the case of a rigid connection would generate a bending moment of $255 \mathrm{kNm}$, which is the same value determined in the connection project.

For each model was considered the stiffness according to its cross section. Model 1 with rectangular cross section and Model 2 with "T" cross section, which was determined in accordance with [9], resulting in two different lines, one for each model. The moment of inertia was calculated in stage I and the elastic modulus was determined based on the specimens' characterization tests. Assuming a bi-supported beam (Figure 17), the rotation of the beam end was calculated according to equation 2. Table 3 shows the values of rotation for each model with their moment of inertia and elastic modulus.

$$
\theta_{A}=\theta_{B}=\frac{l \cdot P \cdot a}{2 \cdot(E \cdot I)_{\text {teorico }}} \cdot\left(1-\frac{a}{l}\right)
$$

Figure 16 - Bending moment versus rotation curves with indication of secant stiffness and Beam-Line
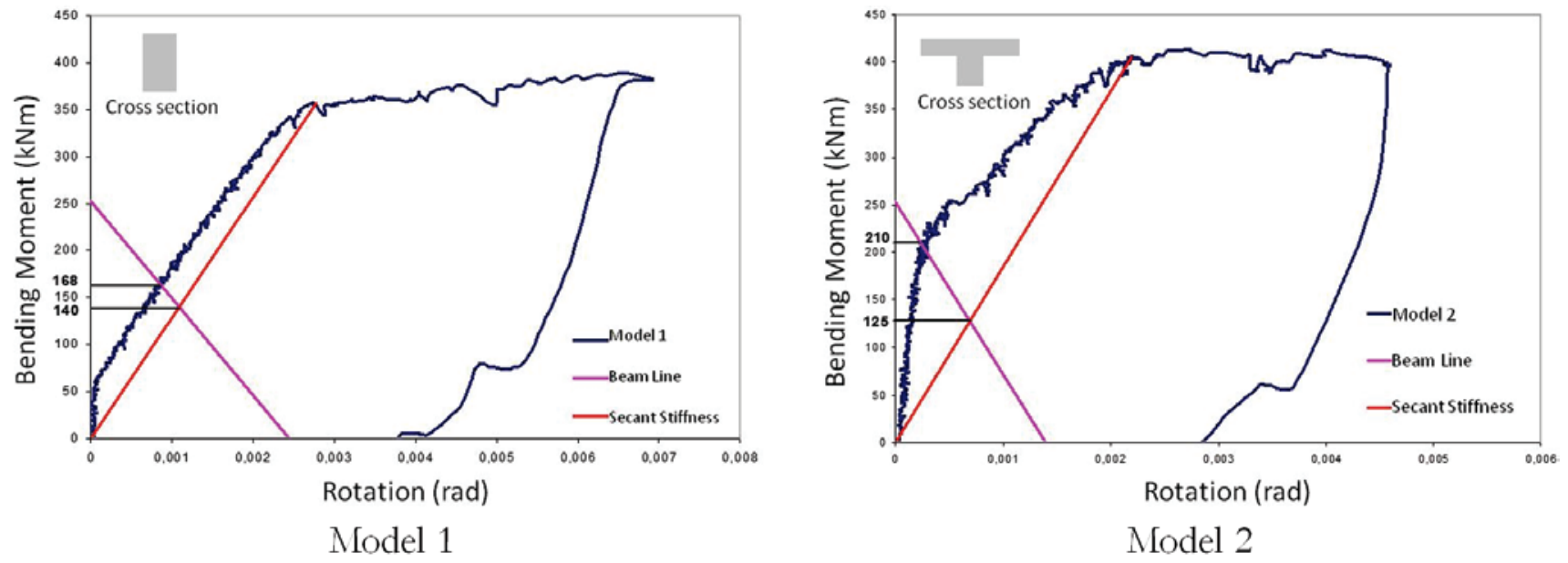
Figure 17 - Scheme for determining the rotation of a bi-supported beam

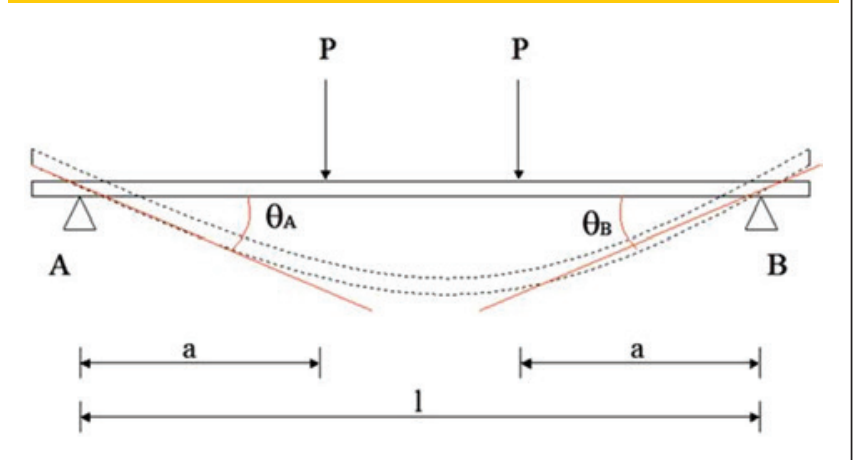

$(E . I)_{\text {teorico }}-$ Theoretical stiffness of the beam

$\ell$ - Beam span

$a$-Distance from the point of load application to support

$\mathrm{P}$ - Concentrated load

The percentage of partially restrained, which reflects the connection percentage of rotation restrained, was determined for experimental stiffness and secant stiffness. In the case of experimental stiffness the analysis was performed in the point of intersection between the Beam-Line and the experimental curve and in the case of secant stiffness, the point was the intersection with the secant line connects the point of zero bending moment to the point of moment related to the yielding stress (Figure 16). To determine the coefficient of partially restrained it was used equation 3 .

$$
\begin{aligned}
& \frac{M_{E}}{M_{R}}=\text { Coefficient of partially restrained } \\
& M_{E}-\text { Bending moment in the connection } \\
& M_{R} \text { - Fully restrained moment }
\end{aligned}
$$

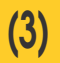

The fixity factor $\left(a_{R}\right)$ was determined in accordance with equation 4 from Ferreira [14], considering the application of two concentrated loads.

$$
\frac{M_{E}}{M_{R}}=\frac{6 \alpha_{R}-3 \alpha_{R}^{2}}{4-\alpha_{R}}
$$

Table 4 shows the results of percentage of partially restrained considering the experimental stiffness and secant stiffness. Model 1 presented closer values of percentage of partially restrained due to its stiffness was not so high. Taking into account the stiffness of Model 2, there was a significant difference between the percentages of partially restrained which were determined to the experimental curve and to the secant stiffness. The percentage of partially restrained to the experimental stiffness reached $83 \%$ and only $49 \%$ for secant stiffness.

According to Ferreira [13], Model 1 was classified as semi-rigid connection with medium strength (zone 3 ) considering the experi- mental stiffness and the secant stiffness. Model 2 presented two different classifications: considering the experimental stiffness is classified as a semi-rigid connection with high strength (zone 4) and considering the secant stiffness is classified as semi-rigid with low strength (zone 2).

\section{Conclusions}

Based on this research, with two tests of connections, it was possible to analyze the behavior of the beam-column connection between precast concrete elements which is widely used on sites and also to test an experimental methodology which is not standardized in Brazil.

- The method used to measure the rotation which employed the transducers placed on the corbels was very satisfactory. The advantage of this method was the possibility to measure rotation created by the opening of cracks in the connection region. The use of clinometers to measure the rotation was also satisfactory. It was possible with the clinometers to obtain the direct measurements of global rotation, whose values were close to those obtained by transducers. With these results the methods were validated.

- In despite of Model 2 had presented high stiffness in service situations, the secant stiffness of the two models were very close. Model 2 reached a percentage of partially restrained lower than the percentage that Model 1 reached. However, it can be concluded that using the secant stiffness in the project of connections the dimensioning is in favor of security. Using the secant stiffness of the connection in design process, the designers will also reserve strength and rigidity to resist to other loads not considered in the project.

- According to the connections classification, both models can be considered with semi-rigid behavior. Despite the classification of Model 2 as semi-rigid with low strength (zone 2) considering the secant stiffness, the reinforcement distribution of this model was the one which provided more rigidity to the connection.

\section{Table 3 - Values of rotation, moment of inertia and elastic modulus for Models 1 and 2}

\begin{tabular}{|c|c|c|c|c|}
\hline \multirow[b]{2}{*}{ Model } & \multicolumn{2}{|c|}{ Experimental Stiffness } & \multicolumn{2}{|c|}{ Secant Stiffness } \\
\hline & $\frac{M_{E}}{M_{R}}$ & $\alpha_{R}$ & $\frac{M_{E}}{M_{R}}$ & $\alpha_{R}$ \\
\hline 1 & $66 \%$ & 0,52 & $55 \%$ & 0,41 \\
\hline 2 & $83 \%$ & 0,70 & $49 \%$ & 0,36 \\
\hline
\end{tabular}

\begin{tabular}{cccc} 
Model & $\begin{array}{c}\text { Rotation } \\
\text { (rad) }\end{array}$ & $\begin{array}{c}\text { Moment of } \\
\text { inertia }\left(\mathrm{m}^{4}\right)\end{array}$ & $\begin{array}{c}\text { Elastic Modulus } \\
\left(\mathrm{kN} \cdot \mathrm{mm}^{2}\right)\end{array}$ \\
1 & 0,002375 & 0,0100 & 30 \\
2 & 0,001340 & 0,0177 & 30 \\
\hline
\end{tabular}

\section{Table 4 - Percentage of partially restrained of the connections}




\section{Acknowledgments}

The authors would like to thank FAPESP by financial support and Protendit by donation of the precast elements that allow the construction of the models.

\section{References}

[01] ASSOCIAÇÃO BRASILEIRA DE NORMAS TÉCNICAS. NBR 9062. (2006). Projeto e Execução de Estruturas de Concreto Pré-moldado. Rio de Janeiro - RJ.

[02] SHARIATMADAR, H., BEYDOKHTI, E. Z. (2011). Experimental investigation of precast concrete beam to column connections subjected to reversed cyclic loads. 6th International Conference on Seismology and Earthquake Engineering. Tehran, Iran.

[03] HAWILEH, R. A.; RAHMAN, A.; TABATABAI, $H$. (2010). Nonlinear finite element analysis and modeling of a precast hybrid beam-column connection subjected to cyclic loads. Applied Mathematical Modelling.

[04] KAYA, M.; ARSLAN, S. (2009). Analytical modeling of post-tensioned precast beam-to-column connections. Materials and Design.

[05] SAQAN, E. I. (1995). Evaluation of ductile beam-column connections for use in seismic-resistant precast frames. Ph.D Thesis. Faculty of the Graduate School of The University of Texas at Austin.

[06] OLIVEIRA JÚNIOR, L. A. (2012). Ligação viga-pilar em elemento pré-moldado de concreto solidarizados por concreto reforçado com fibras de aço: análises estática e dinâmica. Tese de Doutorado. Escola de Engenharia de São Carlos, Universidade de São Paulo. São Carlos. 255p.

[07] BALDISSERA, A. (2006). Estudo experimental de uma ligação viga-pilar de concreto pré-moldado parcialmente resistente a momento fletor. Dissertação de Mestrado. Escola de Engenharia de São Carlos Universidade de São Paulo. São Carlos - SP.

[08] KATAOKA, M. N. (2007). Estudo da continuidade em ligações laje-viga-pilar em estruturas pré-moldadas de concreto. Dissertação de Mestrado. Universidade Federal de São Carlos. São Carlos - SP. 113p.

[09] ASSOCIAÇÃO BRASILEIRA DE NORMAS TÉCNICAS. NBR-6118. (2003). Projeto e Execução de Obras de Concreto Armado. Rio de Janeiro - RJ.

[10] EL DEBS, M, K. (2000). Concreto pré-moldado: fundamentos e aplicações, $1^{\text {a }}$ Edição, EESC - USP, São Carlos, 456 p.

[11] COST-C1 (1996). European Cooperation in the Field of Scientific and Technical Research. Semi-rigid behaviour of civil engineering structural connections Composite steel-concrete joints in braced frames for buildings. Bruxelas, Luxemburgo.

[12] CHEFDEBIEN, A. (1998). Precast concrete beam to column head connections. In: CONTROL OF THE SEMI-RIGID BEHAVIOUR OF CIVIL ENGINEERING STRUCTURAL CONNECTIONS, COST C1 INTERNACIONAL CONFERENCE. Cost C1: Proceedings. Liege, Belgium. P. 35-43.
[13] FERREIRA, M. A.; El Debs, M. K.; Elliott, K. S. (2002). Modelo teórico para projeto de ligações semi-rígidas em estruturas de concreto pré-moldado. $44^{\circ}$ Congresso Brasileiro do Concreto - IBRACON. Agosto, Belo Horizonte - MG.

[14] FERREIRA, M. A, (2006). Study on the semi-rigid behaviour of beam-column connections in precast concrete structures. FAPESP Annual Research Report Brazil. 